\title{
Skandalista Przybyszewski - życiowe i literackie faux-pas młodopolskiego Archicygana
}

Aleksandra Sawicka 


\section{Aleksandra Sawicka}

\section{Skandalista Przybyszewski - życiowe i literackie faux-pas młodopolskiego Archicygana}

$\mathrm{S}$ tanisław Przybyszewski bardziej jest dziś kojarzony ze swoim burzliwym i pelnym skandali życiem niż z utworami, których był autorem. Alkoholik, narkoman i kobieciarz - to współczesne podsumowanie dorobku pisarza. I choć po związaniu się węzlem małżeńskim z Jadwigą Kasprowiczową Archicygan z krakowskiej „Synagogi Szatana” znacznie złagodził tempo i intensywność życia, to dla współczesnych na zawsze pozostanie skandalistą. Trzeba jednak przyznać, że Przybyszewski solidnie sobie na taką opinię zapracowal.

Już z chwilą osiedlenia się w Berlinie Stanisław Przybyszewski zaczął budować swój niechlubny wizerunek: wiąząa się bez błogosławieństwa Kościola z Martą Foerder i płodząc z nią troje dzieci, następnic - wciąż będąc „nieślubnym mężem” Foerderówny - żeniąc się z piękną i adorowaną przez innych Norweżką Dagny Jucl. Bardzo opinii Przybyszewskiego zaszkodziła samobójcza śmierć Marty, która - będąc najprawdopodobniej w kolejnej ciąży i mając świadomość tego, ze pisarz nigdy dla niej nie opuści Dagny — otruła się w czerwcu 1896 roku. Wielu berlińskich przyjaciót miało to pisarzowi za złe, zwlaszcza że ten, podejrzany o przyczynienie się do śmierci Foerderówny, spędzil dwa tygodnie w więzicniu. Echa tych wydarzeń dosięgły także polskiego środowiska literackiego, zwłaszcza w tygoduiach poprzedzających objęcie przez Przybyszewskiego redakcji krakowskiego „Życia”. Jednak zdecydowanie największym skandalem w życiu pisarza stały się burzliwe dwa lata - od czerwca 1899 do czerwca 1901. Wtedy to Stanisław Przybyszewski związal się z zoną Jana Kasprowicza, inicjując jednocześnie romans z malarką Anielą Pająkówną. Po kilku miesiącach oczekiwania na to, że mąż się opanięta, wzburzona Dagny porzucila go, wyjeżdżając z Krakowa w towarzystwie kochanka. Swój żal wobec Dagny i swoje uczucie do Kasprowiczowej Przybyszewski przetworzyl literacko, opisując je w powieści drukowancj na łamach „Chimery”. Była to pierwsza część Synón' ziemi zatytulowana Malaria, której publikacji redakcja pisma zaprzestała, zo- 
rientowawszy się, że utwór ma zbyt autobiograficzny charakter. Z początkiem 1901 roku 1)agny powróciła do męża, co również wywolalo poruszennie w plotkarskim światku, bowiem powszechnie było wiadomo, że Przybyszewski ani myślał zakończyć swój romans z Kasprowiczową. Pojednani małżonkowi osiedli w Warszawie, by po kilku tygodniach skorzystać z łaskawej propozycji przyjaciela rodziny, Whadysława Emeryka, wyjazdı do posiadłości jego rodziców na Kaukazie. W ostatniej chwili Przybyszewski wycofał się, obiecując dotarcie do gruzińskiego Tytlisu kilka dni później. Na początku czerwca, po kilkunastu dniach spędzonych w towarzystwie Emeryka, Dagny zginęła zastrzelona przez niezrównoważonego studenta, który chwilę późnicj popełnił samobójstwo. Iistoria ta zaciążyła na zawsze na biografii Stanisława Przybyszewskiego, nadając mu piętno skandalisty. Warto przyjrzeć się blizej temu epizodowi z życia pisarza.

Przybyszewscy pojawili siç pod Wawelem jesienią 1898 roku. Najpierw przyjechał Stanisław, kilka tygodni później do Krakowa zawitala Dagny z dwójką dzieci - Zenonem i Iwi. Po latach przyjazd Przybyszewskich tak opisywal w swoich wierszowanych wspomnieniach Maciej Szukiewicz:

Bez feniga przy duszy, wieczny ptak niebieski, Przyjechal do Krakowa ,Stacho" Przybyszewski.

Jeszcze dobrze manatków swych nie rozpakowat, A już się wielki rumor począł koło niego

I Kraków o nim ciaggle gadal i plotkowal. (...)

- Ponos jest Przybyszewski, czy to prawda, panie?

- Przyjechal.

- Czy to prawda, czy gadanie ghupie,

Ze w I igilicn bohater ich kocha się w trupie?

- A co jest w De Profundis? Bo ludzie mówili,

Ze mato w I igilien jeszcze nekrofilij,

I jak Byron w Manfredzic, tak on w swej powieści

W noc letnią, podczas burzy, siostrę swą bezcześci. (...)

A prawda o jego żonie? - o jego Duszeńce -

Bo mówią, że już przeszla przez niejedne ręce,

$\dot{Z}_{e}$, podobno, w faworach jest dla mężczyzna hojna.

A czy, przynajmniej, ladna?

- I owszem, przystojna,

A to, czy grzeszy: myślą, mową i uczynkiem,

To jesteśmy, w tych wszystkich sprawach, proszę pani,

Na ludzkie zle języki i na plotki zdani.

Jedno jest tylko prawda (wiem to z pierwszej ręki), 
Ze Strindberg przez rok wielbil jej dziewicze wdzięki,

Niewieścim zaś nasz Zenon dal swój akcent synkiem!

Oczywiście Szukiewicz w swoich wspomnieniach mocno przerysowal aurę skandahı, jaka wytworzyła się wokól „cygańskiego malżeństwa”. Jednak faktem jest, że „Kraków ciągle gadal i plotkowal", bowiem tryb życia, jaki pędzili Przybyszewscy, w niczym nie przypominał tradycyjnej mieszczańskiej egzystencji. Większość czasu spędzali w otoczeniu wielbicieli Stacha w restauracji Ferdynanda Turlińskiego, zwancj popularnie „Paonem”. Stanisław Wyrzykowski po latach wspominał wieczory w „Paonie“:

Pijacką serdecznością serdeczny dla wszystkich bywal tylko Przybyszewski. Udział jego i jego malzonki w Paonie polegal przede wszystkim na pochłanianiu miestychanej ilości alkoholı. Zazwyczaj pijali sami, bo wszyscy inni poprzestawali na czarnej kawic lub herbacie. Pani I agny nie upijała się nigdy. Pod wpływem koniaku, co byl jej ulubionym napojem, tylko nicruchomiala i bladla w odróżnieniu od swego męża, który czerwieniał, stawal się ruchliwym i krzykliwym. Zakończeniem bywały dzikie i wariackie improwizacje fortepianowe ${ }^{2}$.

Także zachowanie samej Dagny wzbudzało kontrowersje. Tadeusz Boy Zeleński, w krakowskich czasach adorator Norweżki, wspominal swoją młodość:

W „Pannie” obieratem zwykle najlepszą cząstkę, szedlem do ogólnej sali na bilard z Dagny Przybyszewską, którą wyuczyłem tej gry. Kobieta grająca w bilard to było dosyć, aby zgorszyć ówczesny Kraków, i niemało przyczynito się do legend o ,orgiach” "Paonu”.

Tak uplynęly Przybyszewskim pierwsze krakowskie miesiące. Akcentem poniekąd podsumowującym ich kawiarniano-rozrywkowy byt staly siç wyprawione pod koniec maja słynne chrzciny Ivi, które tak barwnie opisal po latach Boy ${ }^{\dagger}$. Z początkiem czerwca Dagny wyjechala z dzić́mi do Zakopanego, zaś Przybyszewski zawitał do Lwowa z odczytem. Tam nawiązal zgubny w skutkach romans z Jadwiga Kasprowiczową, a takze - o wiele bardziej dyskretny - związek z malarką Anielą Pająkówną. Dagny dość szybko dowiedziała się o niewierności męża, choć prawdopodobnie miała świadomość wylącznie milostki z Kasprowiczową, Pająkównę tratıjąc jedynie jako jeszcze jedną wielbicielkę talentu męża. Nie trzeba było wiele czasu, by lwowska przygoda Przybyszewskiego stała się znana co najmniej gronu najbliższych pisarzowi osób. Zwłaszcza że urażony do żywego Kasprowicz kazal żonie wybierać między mężem a kochankiem, gdy zaś ta zdecydowała się na życie u boku Przybyszewskiego.

\footnotetext{
' Wspomnicnia Macicja Szukicwicza, zbiory rçkopiśmicnne Biblioteki Jagiellońskicj w Krakowic, sygn. III

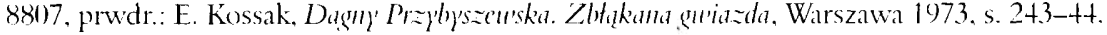

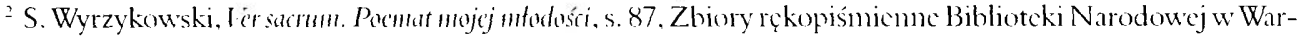
szawic, sygn. III 10)+78, nicpubl.

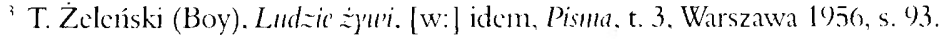

' Por. idem, Znassli ten kraj. [w:] ibidem. t. 2. Warszawa 1956, s. 134.
} 
poeta zabrał córki i wyprowadził się z domu. Romans Archicygana szybko stał się tajemnicą poliszynela.

Dagny dość długo miała nadzieję, że malżonek się opamięta, pisala do niego gorące listy, zapewniając o swojej miłości. Druga polowę roku 1899 Przybyszewska wraz z dziećmi spędziła w Zakopanem. Stanislaw przyjeżdzal tam na kilkutygodniowe pobyty, odgrywając rolę kochającego męża i ojca, zaś w tajemnicy przed żoną wysyłając namiętne listy do Kasprowiczowej i Pająkówny. Tymczasem zaraz po wyjeździe z kurortu udawal się do Lwowa lub Krakowa, gdzie utrzymywal równocześnie dwa pozamalżeńskie związki — z histerycznie rozkochaną w nim Kasprowiczową i z pełną oddania Pająkówną, która wspierała go finansowo i duchowo.

Po kilku miesiącach Dagny Przybyszewska, nie widząc szans na ratowanie małżeństwa, także postarała się o towarzystwo plci przeciwnej. Z początkiem roku 190)( opuściła męża, przeprowadzając się do hotelu w towarzystwie poety Wincentego Brzozowskiego. Wiele lat później niedarzący Przybyszewskich sympatią Ludwik Krzywicki tak interpretował wydarzenia rozgrywające się między malżonkami:

Dagna, maskując swoje zachowanie różnymi teoriami i różnymi emocjami, kompletnie sprzedawała siebie. A co ciekawsze, mąz pchał ją do tego. Pchał, aby się od niej odczepić. Przeszły pierwsze lata upojenia, Dagna była przeszkoda, powstrzymującą szukanie nowych wrażeń i doświadczanie nowych dreszczów. I znowu „dobroć” Przybyszewskiego, ta dobroć, która więcej krzywd ludziom narobila niz postępowanie wolne od dobroci, pchnęła Przybyszewskiego do dziwnych czynów. Nie miał odwagi powiedzenia Dagnie, że chciaby się od niej uwolnić, więc podsuwał jej adoratorów, żeby wywołać taką sytuację, w której rzucilaby go. Dagna adoratorów przyjmowała, Przybyszewski przyłapał ją w zbyt drastycznych objęciach z Brzozowskim, ale oburącz trzymala się Przybyszewskiego, poznała jego słabość, zrozumiała, że z tym czlowiekiem-ścierką wszystko można bylo zrobic ${ }^{5}$.

Odejście Dagny od męża wywołalo w Krakowie skandal. Przybyszewski skarżył się w li. ście do Kasprowiczowej:

Ta pani, którą z domu wyrzucilem, wtrącila mnie w wielkie nieszczęście. Nie mogę sobie dać rady. W jednej clıwili rozszedl się skandal po Krakowie. Wierzyciele zlecieli się jak kruki na żer. Dom mój w ustawicznym i niezmiernie przykrym oblężeniu".

Zwłaszcza że, jeśli wierzyć słowom Przybyszewskiego, Dagny zabrala Zenona i jeszcz przez kilka dni mieszkala wraz z Wincentym Brzozowskim i dzieckiem w krakowskim hote lı. Przybyszewski tak później relacjonował to swojej szwagierce, Ragnlhild Juel Bäckströn 
Dalem jej pieniądze, obiecała, że natychmiast wyjedzie, a jeszcze przez dwa dni bez mojej wiedzy zostala tu ze swoim amantem. Calymi dniami szukakem tego psa, aby zastrzelić go na ulicy, ale ukrył się. Opamiętałen się, że nie mam prawa doprowadzać do zguby całej mojej rodziny. Teraz jestem kompletuie zrujnowany. Lichwiarze przejęli wszystkie meble, całą bieliznę, wszystkie dzicła sztuki i jestem teraz nagi ${ }^{7}$.

Dolaniem oliwy do ognia stało się w tej sytuacji wydrukowanie na tamach „Życia” francuskiego wiersza Wincentego Brzozowskiego À Madame Dagny Przy (b)'szeu'ska, w którym poeta dość jednoznacznic opiewał przymioty pani Przybyszewskicj. Stanisław musial się z tej publikacji mocno thumaczyć przed Jadwigą Kasprowiczową:

Piszesz mi, że Ci wyrządzilèn brutalna przykrość pomieszczeniem jej rzeczy i sonetu Brz. w „Życiu”. To muie - muie, słodkie dziecko, wyrządzono tę przykrość. Sonet Brzoz. dostal się zupełnie bez mej wiedzy i z wielkim niesmakiem czytalem go po wydrukowaniu. Przecież to rzecz wysoce mmic kompromitująca".

Kilka dni po odejściu od męża Dagny dala plotkarzom nowy temat do roztrząsania. Wyjechała z kochankiem z miasta, powodıjąc tym samym kolcjną lawinę przeróżnych spekulacji. Ojej wyjeździe pisała Julia Tetmajerowa w liście z 6 stycznia 19(\%) roku do syna Kazimierza:

Wyobraź sobie, że Dagna opuściła męża i córeczkę i z p. Wincentym Brzozowskim wyjechała w świat. Tadzio [Żeleński - przyp. A. S.] nic o tym nie wiedzial, wstał kicdyś i prosto z lóżka poszedl do niej, i juz nie zastal! Powrócił do domu w stanie okropnym - nic nie powiedział o tym fakcie i nie wiedziałyśmy, czemu ten stan przypisać. On nam wczoraj dopiero opowiedzial o jej wyjeździe, ale inaczej, jak bylo naprawdę - .wyjechała sama, piekło tam się działo nie do zniesienia - bił ją, zabijał mąż za to, że nie jest Polką, za to, że się przy nim nie urodziła" itp. Włodzio rzecz tę przedstawił w innym świetle - oznajmiła wprost, że syn nie jest jego, więc go zabiera z sobą, a córeczkę zostawia i odjechała. - Przewidujemy jednak, ze to dopiero koniec pierwszego aktu i ze się mają z Tadziem zjechać w Wiedniu, bo o ile dotąd utrzymywal, ze nie warto zdawać egzaminów na to, żeby zaraz być zmuszonym wyjeżdzać do Wiednia, o tyle teraz postanawia jak najprędzej pozbyć się tych egzaminów i pojechać zaraz do Wiednia, aby się tam rozejrzeć w tym, co dalej wypadnie z sobą robić. Okropnie jest usposobiony, wszystko w nim zaniklo, co szlachetniejsze, aż przeraża jego smutek, zniechęcenie i cynizm. Jeszcze nic wyszedł powtórnie

\footnotetext{
${ }^{7}$ List S. Przybyszewskicgo do R. Jucl Bäckström z 9 kwictnia 1900 (Kvimemusect w Kongssinger. korespon-

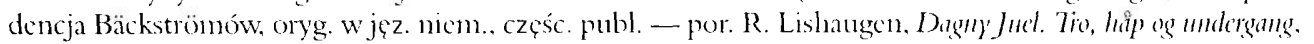
Oslo 2002. s. 181-182).

"S. Przybyszewski. Listy'..., op. cit., s. 249.
} 
i leży po więsszej części. Pewno się obawia ludzi i ich gadania. Zmannowany chlopiec, a tak go żal!'

Dagny wyruszyla do Szwecji, a następnie do Berlina i do Lwowa. Przybyszewski pojechał za nią do stolicy Niemiec, by tam przeprowadzić rozwód. Musial się ze swojej podróży listownie wythumaczyć przed Kasprowiczową:

Nie jadę za nią do Berlina, ona przestała już dla mnie zupełnie istnieć, była kobieta marna, marniejsza, aniżelim przypuszczal, nie dlatego, że to zrobiła, tylko ze zrobila to w brutalny, podly sposób. Zresztą nie ma o czym gadać. Prócz innych niezmienie ważnych, wydawniczych spraw, jadę głównie, by szybko rozwód przeprowadzić, a mogę go tylko w Berlinie. Ona ma się podobno zjechać z panem Wincentym Brzozowskim (...) w Paryżu i jechać do Syrii. Jestem ogromnie zadowolony, że się tak wszystko stało, bo pożycie było nad wyraz męczące, a ona nad wszelki wyraz nieznośna. Teraz mam spokój. W Berlinie pozostanę z jaki tydzień lub dwa, a następnie wracam na stałe do Krakowa. Wynajętem sobie pomieszkanie, niańka pozostaje z dzieckiem"n.

Jednak do formalnego zerwania małżéstwa nie doszło. Natomiast pojawienie się — choć osobne - obojga malżonków w Berlinie wywołalo poruszenie w kręgu dawnych przyjaciól. Malarka Julie Wolfthorn donosila o Przybyszewskich Idzie Auerbach:

Chciałaby Pani jeszcze uslyszéc trochę plotek na drogę? Ducha wybiera się $z$,największym” polskim poetą do Paryża. On (P.[rzybyszewski]) był tu przez 5 dni i pit przeraźliwie".

W lutym Przybyszewska ponownie pojawiła siç w Krakowie. Julia Tetmajerowa, wyjątkowo zainteresowana rodzinnymi problemami Przybyszewskich, zawiadamiała syna:

Przybyszewska powrócila do męża, podobno on jedzie z odczytem do Warszawy ${ }^{12}$.

Z Krakowa małżonek wysłal Dagny - zapewne, by stlumić falę plotek - do Pragi. Zao. piekować się nią w Pradze miał Arnošt Prohazká, wspólpracownik Przybyszewskiego, redak. tor czeskiego pisma „Moderní Revue”. Oczywiście oficjalne powody przyjazdu pani Przyby szewskiej do stolicy Czech były zupełnie inne niż chęć pozbycia się niewygodnej małżonki Przybyszewski pisal do Prohazki:

"Korespondencja Julii Tetmajcrowcj. Bihlioteka PAU-PAN Kraków sygnn. 4658/3, częśc. publ. - po

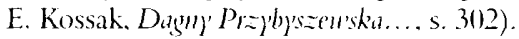

1" Por.: S. Przybyszewski, Listy'.... op. cit.. s. 2+8-2+9.

"List J. Wolfthorn do 1. Aucrbach z 31 stycznia 1900, Staats- und Universitätsbibliothek w Hamburg Dehmol-Archiv. W 533. oryg. w jez. nicm.

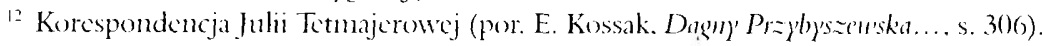


Zmuszony jestem na pewien czas wyjechać na Kaukaz. Dzieci wyshałem do Norwegii. Żona nie czuje się dobrze w Krakowie. Sann też jestem nieco przemęczony miastem, gdzie tyle przecierpiałem; od dawn tęsknię, żeby poznać Pragę i spędzić tam parę miesięcy. Wobec tego żona moja przyjedzie do Pragi teraz, a ja po kilku tygodniach ${ }^{13}$.

W drugiej połowie marca 1)agny, po około miesięcznym pobycie w Pradze, za wszelką cenę chciała wyjechać z tego miasta. Przybyszewski pisat o tym Pająkównie, nie szczędząc jej brutalnych uwag na temat Dagny:

Pani mi pisała list, w którym mi pisze, że jeżeli mann cokolwiek litości już nie nad kobietą, ale obcym człowiekiem, to mam ją wyrwać z Pragi, bo albo oszaleje albo sobie życie odbierze. Na to jej odpisałem, że ma na razie przyjechać do Krakowa, zamieszkać u mnie, aż się postaram o pieniądze [by ją wyprawić do jej kochanka | Na to blagala, by mogla tak dlugo z Iwcią pozostać. Zatelegrafowałem, że zrobię wszystko, co sobie tylko życzy. Więc Iwcię sprowadzam znowu na czas pobytu pani Dagny do Krakowa. (...)

Piekielniem zrozpaczony; ona mi jest zupehnie obcą: dusza moja ją wypluła, ale nie moge pozwolić, by matka moich dzieci zmarniała [albo stala się prostytutką, bo i na to ma dość materialuj $]^{14}$.

Zatrzymawszy się na kilka dni w Krakowie, Dagny ponownie ruszyła w podróż. Tym razem jej celem miał być Paryż. Trzeba przyznać, że siostry Dagny, nie mając z nią kontaktu i wszelkie informacje na temat pożycia Przybyszewskich czerpiąc z listów Stacha, jednomyślnie opowiedziały się po stronie szwagra, bezlitośnie krytykując postępowanie Dagny w swojej korespondencji. Bardzo surowy osąd wyrazila w liście do Przybyszewskiego najbliższa sercu Dagny - Ragnhild:

Każdego dnia bezustannie myślę o Tobie, i nie mogę uwierzyć, że stało się tak, jak mi to opisaleś. Że Dagny mogła Ci to zrobić, Tobie i dzieciom, i że Tobie zniszczyło to cale życie, a ją przede wszystkim skazało na wieczne nieszczęście. I te małe, biedne dzieci! Ale muszę wierzyć, że teraz przydarzy się coś nowego, że wróci do Ciebie i jak żebraczka zostanie z powrotem przyjęta w Twój dom. Jak mogła Cię opuścić, Stachu, kiedy bỵla traktowana jako Bóg, i odejść z jakimś mlodym, śmiesznym poetą i cała rzucić się w plugastwo? Czyżby straciła calą swoją dumę i poczucie wlasnej godności? Gdybym tylko mogla do niej na-

\footnotetext{
13 S. Przybyszewski, Listy.... op. (it., s. 250.

${ }^{1}$ Ibidem. s. 253. S. Helsztyński opuścil w swoin wydaniu listów pisarza fragnenty w nawiasach klamrowych, znajdujz siç one natomiast w oryginale (zbiory rękopišnicnne, Zaklad Narodowy im. Ossolinskich we Wroclawiu, korespondencja S. Przybyszewskicgo, sygn. 13051 II)
} 
pisać, - ale nie mam przecież adresu, i jeszcze tylko pogorszylabym sprawę, a ona przecież wie, jak bardzo Cię kochann ${ }^{15}$.

Rodzina I agny podjęła kroki mające na celu sprowadzenie niepokornej Dagny do Norwegii. Z dala od wielkiego świata latwiej byłoby ukryć wstydliwe przygody pani Przybyszewskiej. W polowie roku Dagny udała się do rodzinnego Kongsvinger.

Tymczasem Przybyszewski, na dobre pozbywszy się niewygodnej małżonki, zlikwidował ostatecznie swoje krakowskie mieszkanie i przeprowadzil się do Lwowa. Oficjalnie przyczyną zmiany miejsca zamieszkania miały być interesy wydawnicze, ale jedynym powodem osiedlenia się we Lwowie była tak naprawdę Jadwiga Kasprowiczowa, bardzo zaborcza w swoim uczuciu do Stacha. Z końcem roku pisarz zajął się opracowywaniem swojej nowej powieści przygotowywanej na zamówienie Zenona Przesmyckiego. Zamierzał w niej zawrzeć między innymi, czerpiąc pelnymi garściami z własnych doświadczeń, historię pewnej niewiernej żony porzucającej męża. Do sprawy tego utworu jeszcze powrócę.

Oczywiścic przed najbliższymi, zwłaszcza przed matką, Przybyszewski staral się trzymać fason, przedstawiając swoją sytuację w jak najkorzystniejszym świetle. Pisal do matki:

Droga mamo, Tak źle znowu nie jest ze mma, jak sobie mamuchna wystawia. Jestem chwilowo w przykrym położeniu, ale za jaki miesiąc stosunki moje już calkiem będą uregulowane. Tylko mi niezmiernie przykro, że mama wierzy tym wszystkim plotkom, które oczywiście o czlowieku, który przez tak długi czas prowadzil calą generację mlodych pisarzów i ich wychowywal, krążyć musząi ${ }^{16}$.

Co zaskakujące, dość szybko po przyjeździc Dagny do Skandynawii - być może za namową rodziny - rozpoczęły się między małżonkami pertraktacje mające na celu ich ponowne połączenie się. Już pod koniec lipca Julie Wolfthorn donosiła Idzie Auerbach:

Jeszcze kilka nowinek: Ducha powinna się znowu pogodzić z P.[rzybyszewskim], po tym jak on sprawiał jej kłopoty i musieli się rozstać z powodu mlodego największego polskiego poety ${ }^{17}$.

Rzeczywiście, wzmianki na temat rychłego pogodzenia się Dagny i Stacha wielokrotni pojawialy się w rodzinnej korespondencji. Jednak dopiero na początku grudnia zapadła osta teczna decyzja o powrocie Dagny do Polski. W Krakowie, gdzie malzonkowie spotkali się pı wielomiesięcznym rozstaniu, Dagny pojawiła się w drugiej połowie stycznia. Po miesiąc Przybyszewski wyjechali do Warszawy, gdzic — z dala od galicyjskich plotkarek - mieli roz

${ }^{15}$ List R. Jucl Bäckström do S. Przybyszewskiego bez daty [po 9 kwietnia 1900] (oryginal w Muzeum im. Jaı Kasprowicza w Inow ruchawiu, syg̣n. MKI-R/3)8, oryg. w jęz. nicm., częśc. publ. - por. R. Lishaugen, Dag' Juel.... s. 184. Korzystalam z kopii udostępuionej przez Kvinnemusect w Kongsvinger).

is S. Przybyszewski. List'.... op. cit., s. 261.

17 List J. Wolfthorn do I. Auerbach z 25 lipca 1\%(0), Staats- und Universitätsbibliothek w Hamburg Dehmel-Archiv: W 539. oryg. w jez. nicm. 
począć nowe życie. Jednak Przybyszewski wciąż utrzymywal swoje pozamałzeńskie relacje. Już po ponownym połączeniu się z Dagny spłodzil z Anielą Pająkówną córkę - późniejszą pisarkę Stanisławę Przybyszewską - któna przyszla na świat 1 paździennika 1901 roku.

Tymczasem ledwo przycichł skandal związany z rozstaniem malżonków, a wybuchl nowy, tym razem sprowokowany przez pisarza. W styczniowym numerze "Chimery” ukazal się pierwszy fragment powieści S Ynon'ie ziemi, a dokladnie jej pierwszej części zatytułowanej $M a-$ laria. Przybyszewski od samego początku nie ukrywał autobiograficznego charakteru tej powieści. W jednym z listów do Zenona Przesmyckiego wyznawał wprost, kto jest pierwowzorem jego postaci:

Teraz jestem szczęśliwy. Piszę bezustannie i z wielką latwością.

(...) „Sceny z życia krakowskiej literatury”, he, he... W tym, co Ci przesłałem i co Ci przesyłam, zawarta ekspozycja, nazwiemy go Malaria — drugi będzie się nazywat Zmierzch - dostaniesz go do 15 stycznia; bo pierwszy rozdzial juz mam, a teraz to wszystko pójdzie gwaltownie. Do 1 marca cała powieść będzie skoniczona. (...)

Wiesz, że gdyby nic jeden ustęp w Twoim liście, to bylbym Ci rzeczywiścic zawód robil, bo przecież z pustego w próżne nie naleję. (...)

Ale nagle przed czterema dniami czytam Twój list: „Zdaje się, że nowe źródla się w Tobie otworzyły.” W jednej chwili stanęla mi przed oczani Jadwiga K. W tej jasuej sekundzie miałem postać Hanki Glińskiej, bohaterki Symóu' zicmi - Ciebie nie spotka zawód, a ja tworzę wielką rzecz. Bo rzeczywiście otworzyly się nowe źródla - ona je wreszcie otworzyla swą milością i dobrocia, i tym, ze muie kochać nauczyla ${ }^{\text {is. }}$.

Łatwo było odnaleźć w bohaterach $S_{y^{\prime} n o ́ u}$ zicmi - Czerkawskim, jego żonie i I Iance Glińskiej - osoby Przybyszewskiego, Dagny i Kasprowiczowej. Pisarz przelat na papier cała swoją niechęć do żony i miłość do kochanki. Zona Czerkawskiego, która - notabene - w powieści nie została obdarowana nawet whasnym imienien, to zimma i wyrachowana kobicta, w przeciwieństwie do serdecznej i pełnej uczuć I lanki. Czerkawski tak wsponinal swoją żonę, która opuścila go dla innego:

Czy ją kochał kiedy? Kochał ją rzeczywiście? Byłaż to tylko próżność, że ma za zonę piękną i podziwianą panią?

(...) Próżność ich połączyła, związała, skuła, potem dzieci silniej jeszcze węzly zadzieżgnęly - no tak!

On byl slawny, ona owiana egzotycznym urokiem - tak! i ten zamglony, tajemniczy głos, poza którym żadnej tajemnicy nie bylo, bo dusza jej płytka, próżna i mialka... 
(...) Nie kochał jej, ale chcial, by ona go kochała. A ona go nie kochała i kochać nie mogla, bo dusza jej za plytka i za miałka".

Nic dziwnego, że Dagny, która początkowo, nie znając jeszcze treści utworu, robiła wszystko, by zyskać dla niego wydawców, przyjęla Malarie jako bezpardonowy atak. Miała nadzieję, że zle czasy dla malżeństwa Przybyszewskich się skończyły, a tymczasem publikowana w „Chimerze” powieść świadczyła o czymś zupełnie imnym. Zdruzgotana Dagny pisała do Przybyszewskiego, który w tym czasie przebywal we Lwowie:

Tak Stasiu, Stasiu, na Boga w niebiesiech, byłam zupetnie zmieszana. W końcu nie wiedziałam, co począc. Teraz, w tych ostatnich dniach przeczytalam Twoją powieść w „Chimerze” — tyle po polskujuz umiem - tak, możesz sobie wyobrazić, co się we mnie w środku dzialo! Dobry Boże! Kiedy Zenon zasnął wczorajszego wieczora, godzina za godziną siedziałam skamieniala przy stole, wyjąc jak chore zwierzę. Czulam, że nie moge żyć, że to byłoby z mojej strony największe świństwo żyć dalej.

A dzisiaj, kiedy dostałam Twój list, Twój tak cieply list, pełen czułości, który brzmial tak szczerze, myślç znów, że życie jest możliwe, że może przynieść dobre dni i może nawet być odrobinę szczęśliwe, ale boję się mojego niepoprawnego optymizmu, wiem przecież, że kochasz mnie tylko „par distance”, że kiedy muie widzisz i słyszysz mój głos, Twoje serce napełnia się powoli tą starą nienawiścią, która znalazła tak brutalny wyraz w Twojej powieści ${ }^{20}$.

Nie tylko Dagny dotknęła do żywego treść Sy'nóu ziemi. Cały świat literacki Warszawy, Krakowa i Lwowa wiedział, o kim tak naprawdę pisze Przybyszewski. Ignacy Sewer-Maciejowski w liście do Tadeusza Micińskiego nie kryl swego zgorszenia:

Przybyszewski w „Chimerze” drukuje powieść o pobycie swoim w Krakowie z Dagny. W powieści tej pisze, że Dagny zrobiła z je go dom u „dom publiczny", on to widział i na to pozwalal!... Jest to skończony nikczemnik, uwiódl tu we Lwowie biedną, nieszczęśliwą sierotę, ob da rł ją z pieniędzy i pojechat do Warszawy do Zenona Przesmyckiego, i tam ma się znów polączyć z Dagny, i wspólnie operować młodzież. Jest to podlec, cynik i kryminalista, jakiego nic tak latwo spotyka się w Europie... Kochany Tadku, malo się znasz na ludziach - ja go od razı odgadlem węchem przez skórę².

\footnotetext{
"S. Przybyszewski. Symouric ziemi, Lwów-Warszawa 1904. s. 25.

20 List 1). Przybyszewskicj do S. Przybyszewskiego bez daty [zapewne przed 27 marca 1901] (zbiory prywat1

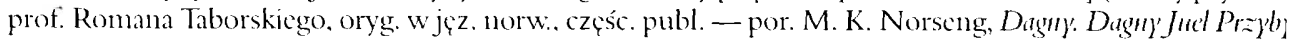
sz'uskd, the Whiman and the Myth, Seattle-London 1991. s. 161).

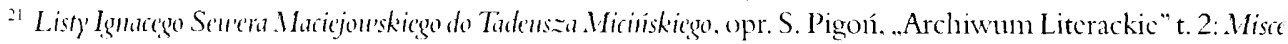
lancul litcriackic 1864-1911). Wrochaw 1957. s. 31+-315.
} 
Głosy oburzenia w warszawskim światku towarzyskim byly na tyle liczne, że Przesmycki zdecydował się przerwać druk powieści. Ostatni jej fragment ukazał się w numerze z kwietnia-maja 19()1 roku, zatem tuż przed wyjazdem 1)agny z Warszawy.

Przybyszewscy oficjalnie znów byli kochającym się małzeństwem, ale tych kilka tygodni w Warszawie Dagny spędziła w przeważającej części z dala od męża. Pod pretekstem załatwiania spraw związanych z prapremiera dramatu Ztote muno pisarz całymi tygodniami przebywał we Lwowie. W Warszawie pojawiał się tylko z krótkimi, kilkudniowymi wizytami. Dagny zdana była na towarzystwo krakowskich adoratorów, którzy także od jakiegoś czasu bawili w Warszawie. Jednym z nich był poeta Stanisław Korab-Brzozowski, brat Wincentego, od niedawna współpracownik „Chimery”. Pod koniec kwictnia Stanisław z niewyjaśnionych przyczyn popetnił samobójstwo. Oczywiście dopatrywano się w tym zgubnych wplywów nauk Przybyszewskiego i nieodwzajemnionej milości do Dagny. Jak zwykle pragnąca być najlepiej o wszystkim poinformowana Tetmajerowa dopytywala Kazimierza Przerwę-Tetmajera:

Czy znasz powód samobójstwa Brzoz.[owskiego]? Czy aby Dagny w tym nie figuruje? On przepadl - nic się o nim nic wie ${ }^{22}$.

Wkrótce miało nastapić to, co stało się apogeum skandalu w życiu Przybyszewskiego. W Warszawie bawił dawny znajomy Przybyszewskich, wielbiciel Dagny, zafascynowany wizjami Stacha dwudziestojednoletni Władysław Emeryk. Plotka głosiła, że Emeryk to czlowiek niesłychanie bogaty, bowiem jego ojciec jest właścicielem kopalni manganu na Kaukazie. Młody Emeryk już wcześniej wysuwał wobec Przybyszewskich propozycje ugoszczenia ich w posiadtości rodziców. Wiosną 1901 roku pisarz i jego żona zdecydowali się skorzystać z uprzejmego zaproszenia. Jednak w ostatniej chwili Przybyszewski wymówił się od wyjazdu obowiązkami literackimi we Lwowie. Obiecal dojechać za kilka dni razem z córeczką. Tak więc do Gruzji Dagny wyruszyła wraz z małym Zenonem w towarzystwie Whadysława Emeryka. Kilka tygodni później do Polski dotarła wiadomość o tyfliskiej tragedii — Emeryk zastrzelił Dagny, zaś sam popełnił samobójstwo. Przybyszewski, który w pierwszej chwili poczul się wreszcie uwolniony od niewygodnej malżonki, w cynicznych słowach zawiadamial o wszystkim kochankę:

Ituchma najsłodsza, Pani Dagny odebrala sobie życie razem z Emerykiem. Przeczytaj „Kurier Warszawski” z 5 czy 6 czerwca i przekonasz się, że prawda. Kocham Cię, jadę, wezmę Zenona ze sobą - i wracam².3.

Oczywiście śmierć Dagny wywołała kolejną talę plotek. Stanisław po raz kolejny thumaczył się przed Kasprowiczową:

22 Korespondencja Julii Tetmajerowcj (por. E. Kossak, Daqun' Przyly'szcu'sk'a..., s. 35.5).

${ }^{23}$ Liścik Stanisława Przybyszew'skiego do Jadwigi Kasprowiczowcj napisany na blankiccic telegramu bez daty [zapewne ok. 7 czerwca 1901] (oryginal w Muzeum im. Jana Kasprowicza w Inowroclawiu, sygn. MKI-R/349, nicpubl. Korzystałam z kopii udostępnioncj przez Kvinnemusect w Kongsvinger). 
Jedna rzecz, która Cię mogła zaboleć, a mnie na klancę wystawić. Otóż w notatce w „Kurierze Warsz.” stało, że ja miałem za nią podążyć razem z Iwcią. Na moje zapytanie, dlaczego takie świadome klamstwo popełniono, odpowiedziano mi, że chciano muie oslonić, bo rozeszła się pogłoska po Warszawie, że kolportowana przez Brz. [ozowskiego] we Lwowie, żem żonę Emerykowi sprzedat i jestem wszystkienu winien ${ }^{2+}$.

Tragiczna śmierć Dagny wywolala falę plotek także w Berlinie i Skandynawii. W niemieckich, szwedzkich i norweskich pismach ukazały się artykuły poruszające ten drażliwy temat. Rodzina zmarłej musiala zmagać się z natręctwem ciekawskich. Ragnhild Juel Bäckström pouczała męża, co ma mówić, jeśli ktoś zapyta o okoliczności śmierci Dagny:

Stachu, Dagny i dzieci mieli zamieszkać przez kilka lat na Kaukazie, zaproszeni przez starych Emeryków. Tymczasem Stachu musial przez miesiąc pozostać we Lwowie z powodu pracy, a I agny nie chciała ani jechać do Lwowa, ani pozostawać sama w Warszawie. Zdecydowała się pojechać w towarzystwie młodego Emeryka (.po zapewnieniu rodziców”). Dagny znaleziono ubraną na szezlongu o godzinie 13.. po tym jak zjadła śniadanie, zaś Emeryk prawdopodobnie podał jej w winie środki nasenne, aby ją zaskoczyć. Tego samego dnia Dagny wysłała do Stacha telegram: „Natychmiast wyślij paszport”, więc wyraźnie bała się go [Emeryka]. Miała ze sobą 12(0) koron na podróż; te 6 rubli znalezione przy niej świadczą o tym, że policja nieźle się obłowiła ${ }^{25}$.

Z biegiem czasu skandal wokół romansu Przybyszewskiego i śmierci jego żony ucich1, zwlaszcza gdy po kilku latach Stanislaw zawarłlegalny związek z Kasprowiczową. Utemperowany przez malzonkę Przybyszewski przycichł i uspokoił się, pędząc od tej pory życie bardziej mieszczańskie niż artystyczne. Wciąż mial problemy z nadużywaniem alkoholu i narkotyków, jednak zarówno trzymająca go twardą ręką żona, jak i słabnące zdrowie nie pozwalaly już na wybryki, jakich dokonywał w czasach swej mlodości. Po latach Stanisław Przybyszewski przypominal bardziej dobrotliwego dziadunia niż demonicznego Archicygana. Jednak burzliwe lata w Berlinie i Krakowie, a zwlaszcza okres romansu z Kasprowiczowa, rozstanic z żoną i śmieré Dagny w Tyflisie na zawsze pozostawiły w jego życiu piętno skandalisty.

2+ S. Przybyszew'ski, List\}’.., op. cit.. s. 272.

25 List R. Jucl Bäckström do H. Bäckströma z 1 sicrpnia 1901 (Kvinnemuscet w' Kongsvinger. korespondencj Bäckströmów, oryg. w j̧̨z. norw., nicpubl.). 